\title{
Fish predation on brachyuran larvae and juveniles in the Pinheiros river, Guaratuba Bay, Paraná, Brazil
}

\author{
Paulo V. Costa ${ }^{1}$; Ubiratã A. T. da Silva ${ }^{1}$; Robson Ventura ${ }^{2}$; Antonio Ostrensky ${ }^{1} \&$ Leandro Angelo ${ }^{1}$ \\ ${ }^{1}$ Grupo Integrado de Aquicultura e Estudos Ambientais, Universidade Federal do Paraná. Rua dos Funcionários 1540, Juvevê, \\ 80035-050 Curitiba, Paraná, Brasil. \\ ${ }^{2}$ Centro de Desenvolvimento em Aquicultura e Pesca, EPAGRI. Rodovia Admar Gonzaga 1118, Itacorubi, Caixa Postal 502, \\ 88034-901 Florianópolis, Santa Catarina, Brasil.
}

\begin{abstract}
Fish predation is thought to exert an important influence on the demographical dynamics of larvae and juveniles of estuarine brachyuran crabs but few studies have investigated this phenomenon in nature. In this study, fishes were captured during full moons (in January and February 2005), when many brachyuran species are known to release their larvae. Samples were carried out in the Pinheiros river, Guaratuba Bay, Paraná, Brazil. The stomach contents of collected fishes were surveyed to determine the species that are most likely to prey on brachyuran immature forms in this location. Two techniques were used to capture fishes: manual samplings, using a 5-mm mesh size net (1.8m depth), and bottom trawling with a $20-\mathrm{mm}$ mesh size net. The collected specimens were fixed using $10 \%$ formaldehyde and preserved in 70\% ethanol. A total of 2941 fishes of 43 different species were collected and the stomach contents of 962 individuals were analyzed in laboratory. Food items were identified and quantified. The fish species captured using manual nets that showed the highest number of preyed zoeae per stomach was the clupeid Platanichthys platana (Regan, 1917). Sphoeroides testudineus (Linnaeus, 1758) and Centropomus parallelus Poey, 1860 showed the highest levels of predation on megalopae. Of the fish species captured using trawl nets, Genidens genidens (Cuvier, 1829) showed the highest average number of zoeae per analyzed stomach and Bairdiella ronchus (Cuvier, 1830) was the most important predator on brachyuran megalopae and on young juveniles. The obtained data indicate that brachyuran crab restocking efforts performed in the Guaratuba Bay should include strategies to avoid or, at least, reduce the access of fishes to the released early juvenile stages, given the potential substantial losses caused by fish predation. Considering that, in general, predation potential was 8.5 times lower in juveniles than in megalopae, releasing immature forms produced in laboratory in the juvenile phase or releasing megalopae into tethered areas and maintaining than under this condition until they reach the juvenile phase may be tested as a method to reduce losses given to fish predation.
\end{abstract}

KEY WORDS. Crab; megalopae; Osteichthyes; predator; Ucides cordatus; zoeae.

The reproductive strategies of aquatic invertebrates often involve synchronized events of mating (CHRIsTy 1978), hatching (Anger et al. 1994, Morgan 1990, Morgan \& Christy 1994), and settlement (Keogh \& Downes 1982, Roughgarden \& Possingham 1988). The timing of these events has a deep influence on adult population structure. Several brachyuran crab species are known to spawn at high tides and at night (DeCOURSEY 1983, Forward 1988, Morgan 1995). According to Christy (2003), the best theory to explain this pattern is the predator avoidance hypothesis, in which nocturnal spawning would hamper the visual identification of larvae by predators (ZIEGLER \& ForWARD 2005). In addition, the timing of dispersal of larvae during high tides could maximize the chances of larvae to be transported to areas with fewer predators, i.e. deeper offshore areas (Forward 1988, Morgan 1995). In spite of these strategies, several researchers consider predation as the most important cause of mortality of marine invertebrate larvae (THORso 1950, YounG \& CHIAN 1987, Lindquist \& HAY 1996), not only during the dispersal, but also during the settlement and post-settlement period (Olafsson et al. 1994, Hunt \& Scheibling 1997).

Understanding predation pressures is particularly important in crustacean restocking efforts. It has been suggested that the release of C1 stage juveniles of the brachyuran crab Portunus trituberculatus (Miers, 1876), Portunidae, carried out in primary restocking programs did not significantly contribute to the fisheries due to predation losses (SECOR et al. 2002), whereas later studies have shown that the release of larger juveniles (C4 instar) resulted in higher survival rates (ARIYAMA 2000).

In Brazil the first crab restocking program started in 2001 using the ocypodid Ucides cordatus (Linnaeus, 1763) (Ocypodidae). Recently, experimental releases of $U$. cordatus larvae have been conducted in the Guaratuba Bay, Paraná, Brazil, as a model 
to improve the knowledge about the restocking techniques of this species. The aim of the present study was to identify the fish species that prey on brachyuran larvae and young juveniles in the Guaratuba Bay, Paraná, Brazil. Furthermore, we investigated the potential of predation of these fish species based on their abundance in the estuary during the events of dispersion, reinvasion and settlement of $U$. cordatus.

\section{MATERIAL AND METHODS}

\section{Study site}

The Guaratuba Bay $\left(25^{\circ} 52^{\prime} \mathrm{S}, 48^{\circ} 39^{\prime} \mathrm{W}\right)$ is an important estuarine system of the coast of the state of Paraná, Southern Brazil. It is connected to the Atlantic Ocean through an approximately $500 \mathrm{~m}$ opening (Fig. 1). Its area is about $45 \mathrm{~km}^{2}$, extending inland nearly $15 \mathrm{~km}$. The vegetation on its margins is composed by mangrove forests (CHAvEs \& CORRÊA 1998). Based on its geographical position, the water flow from the West comes from the mainland, whereas the water flowing from the East is of marine origin (CHAVEs \& BOUCHEREAU 2004). Water abiotic parameters, such as salinity and temperature, range between 3-37 and $28-15{ }^{\circ} \mathrm{C}$, respectively. Lower temperatures and higher salinities occur during the winter and higher temperatures and lower salinities during the summer (Chaves \& Vendel 1997).

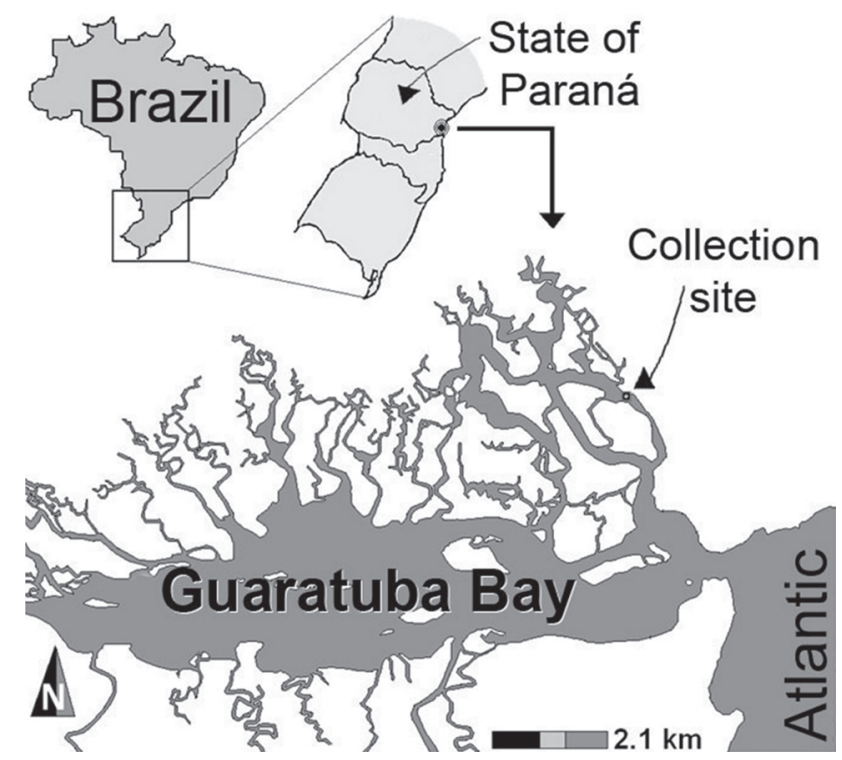

Figure 1. Location of the Guaratuba Bay and the sampling location.

Although marine waters enter the Pinheiros river (254' $51,78^{\prime \prime}$ S, 48 $34^{\prime} 43,99^{\prime \prime} \mathrm{W}$ ) (Fig. 1) during the high tides, continental waters have an more important influence on its salinity (Bigarella 1957). The margins of this river are populated by several crab species as Aratus pisonii (Milne Edwards,
1837), Sesarmidae; Goniopsis cruentata (Latreille, 1802), Grapsidae; U. cordatus, Uca maracoani (Latreille, 1802), Ocypodidae; Uca leptodactyla Rathbun, 1898, Ocypodidae; and Uca uruguayensis (Nobili, 1901), Ocypodidae.

\section{Sampling program}

The sampling program used in the present study was established based on information about the dispersion, reinvasion and settlement of brachyuran species found in literature. According to CHRISTy (2003), many intertidal crab species have semi-lunar or lunar reproductive cycles and most of them release their larvae at night, and on large amplitude ebb tides. This way, larvae are transported rapidly seaward to safer waters where they develop. This same author reported that, after larval development, megalopae are transported biweekly by higher velocity currents to paternal habitats during larger amplitude flood tides.

Fishes were captured during the full moon, on January 25 and February 25, 2005, in the Pinheiros river, using two techniques: 1) manual fishing using multifilament net $(1.80 \mathrm{~m}$ in height, $9 \mathrm{~m}$ in width, and $5 \mathrm{~mm}$ mesh size); and 2) bottom trawling (using 20-mm mesh size multifilament net with a $1.5 \mathrm{~m}$ opening and trawl doors $60 \mathrm{~cm}$ in height). In January, samples were generally obtained during the ebb tide, and thus when brachyuran larval dispersion is likely to take place, and in February during the flood tide, when reinvasion and settlement typically occur. The sampling schedules were determined based on the expectation of tide depth to capture fishes during the beginning, middle, and end of the ebb tide (January 25) and of the flood tide (February 25). However, some logistic problems have hampered the first sampling efforts and only two manual samplings were carried out in January, the first one approximately 1.5 hours after low tide.

Manual fishing was carried out by two persons pulling the net against the tidal stream, near the river margins (approximately $1.5 \mathrm{~m}$ in depth). After 10 minutes, the net was closed and transferred to a boat. After that, fishes were removed from the net and transferred to labeled vials filled with $10 \%$ formaldehyde. An area about $300 \mathrm{~m}^{2}$ was sampled in each effort. In the first manual fishing effort (January 25), two sampling events were conducted: one started at 00:00 and other at 07:00 h. In the second event (February 25), three sampling events were conducted, starting at 00:00, 02:00, and 04:00 h, respectively.

During bottom trawling, the net was dragged by a 26 feet trawler at a constant speed of two knots. In the first trawling effort (January 25), samplings started at 06:00, 08:00, and 10:00 $\mathrm{h}$, respectively. In the second event, samplings started at 00:00, 02:00, and 04:00 h. Each sampling lasted for $10 \mathrm{~min}$ utes. Trawl contents were transferred to the boat at the end of samplings and fishes were removed from it. Each fish was sacrificed by spinal section and transferred to labeled vials filled with $10 \%$ formaldehyde.

In the laboratory, fishes were transferred to vials with $70 \%$ ethanol. All specimens were identified and measured (total length 
- TL). Generally, at least 15 individuals of each captured species of each sampling event had their stomach contents analyzed. In the case of species in which less than 15 individuals were collected, all specimens were analyzed. Occasionally, some fishes could not have their stomach content analyzed due to their small size or poor conservation of internal organs.

Stomachs were surgically removed and all contained items identified and counted under a stereoscopic microscope. Given that some fish species are very abundant in the estuary and the stomach content analysis of all individuals could be impractical, we established a formula to estimate the total brachyuran immature forms preyed by the collected fishes. This estimate was the result of multiplying average number of brachyuran immature forms found in the stomach content analyses by the total number of captured fishes. This factor was described along text as the Predation Potential.

\section{RESULTS}

A total of 2,941 fishes from 43 species were captured. Ten fish species were captured using both fishing techniques. Comparisons about the size of the specimens of this group have shown that fishes captured using manual nets were 3.2 times smaller than fishes captured using trawling nets (Tab. I).

The stomach contents of 962 fishes were analyzed, 531 from manual collection and 431 from trawl samples. Twelve food items were identified, including larvae and young juveniles of brachyuran crabs and specimens of the classes Copepoda, Polychaeta, Gastropoda, Bivalvia, Insecta, Actinopterygii, of the suborder Dendrobrachiata, of the order Stomatopoda, and of the phylum Nematoda. A total of 2,609 brachyuran immature forms were found in the analyzed stomach contents: 1817 in fishes captured manually and 792 in fishes captured using bottom trawl.

Table I. Relationship between fish species captured during manual samplings in Pinheiros river, Guaratuba Bay, and the average of brachyuran immature forms found in the stomach content analysis. Species that did not preyed upon brachyurans were not included in the table. The predation potential was determined by multiplying the average of preyed larvae by the total of captured fishes. Species typed in bold were captured both with manual nets and bottom trawling.

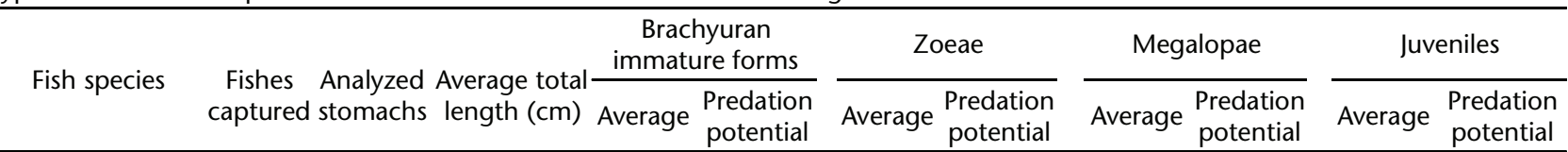

Engraulidae

A. parva

A. lepidentostole

$394 \quad 75$

5.2

$0.44 \quad 173.36$

0.16

63.04

4.1

$1.35 \quad 1362.97$

$1.35 \quad 1362.97$

0.28

110.32

0.00

0.00

Atherinopsidae

A. brasiliensis
Centropomidae

C. parallelus

Paralichthyidae

\section{C.arenaceus}

C. spilopterus

$168 \quad 48$

6.1

1.19

199.50

1.13

189.00

0.00

0.00

0.00

0.00

Gerreidae

\section{D. rhombeus}

$532 \quad 75$

3.4

2.53

1347.83

$2.52 \quad 1340.64$

7.19

Syngnathidae

H. reidi
H. unifasciatus

$\begin{array}{ll}1 & 1\end{array}$

12.0

3.00

3.00

0.00

0.00

0.00

0.00

3.00

3.00

Clupeidae

P. platana
Tetraodontidae

$27 \quad 18$

10.3

0.06

1.50

0.06

1.50

0.00

0.00

0.00

0.00

$91 \quad 48$

4.7

$25.83 \quad 2350.83$

$25.60 \quad 2329.98$

0.23

20.85

0.00

0.00

S. testudineus

$60 \quad 46$

3.8

3.65

219.13

0.09

5.22

3.07

183.91

0.50

30.00

Cynoglossidae

S. tessellates

$4 \quad 2$

4.7

0.50

2.00

0.50

2.00

0.00

0.00

0.00

0.00 


\section{Manual samplings}

Of the species captured using this technique (Tab. I), Platanichthys platana (Regan, 1917), Clupeidae, showed the highest number of brachyuran immature forms per analyzed stomach, with a particularly large proportion of zoea preyed. Larger quantities of zoeae consumed by $P$. platana were detected during the first sampling effort (January 25, 2005) (Fig. 2), when estuarine Brachyuran crabs typically release their larvae (CHRISTY 2003).

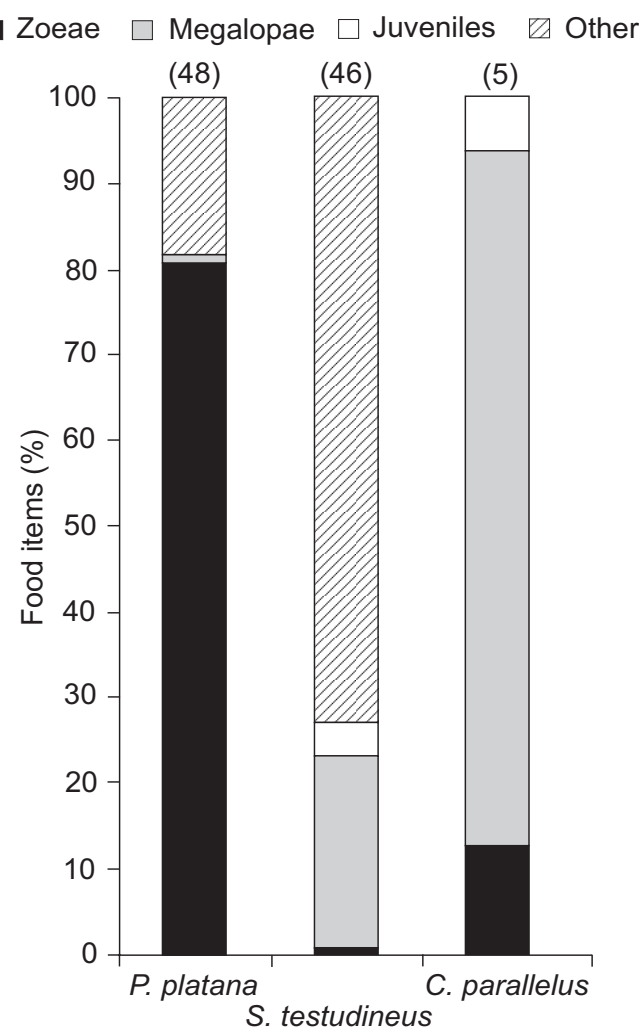

Figure 2. Food items found in the stomachs of fishes captured in Pinheiros river, Guaratuba Bay, during manual samplings and identified as important predators of brachyuran larvae and juveniles. The number of analyzed individuals is described in parentheses.

The most important predator of megalopae identified during stomach analysis was Sphoeroides testudineus (Linnaeus, 1758), Tetraodontidae, followed by Centropomus parallelus Poey, 1860 , Centropomidae. A total of $80.6 \%$ of the food items identified in the stomach content of $P$. platana specimens were brachyuran zoeae. In the stomachs of $C$. parallelus, $81.3 \%$ of the food items were brachyuran megalopae (Fig. 3) and, in the stomach of the only captured Hippocampus reidi Ginsburg, 1933, Syngnathidae, individual, 30\% of food items identified were brachyuran juveniles. In some analyzed C. parallelus stomachs, all of the identified food items were brachyuran immature forms.
Fish species that have shown the highest zoeae predation potential were P. platana, Diapterus rhombeus (Cuvier, 1829), Gerreidae, and Anchoviella lepidentostole (Fowler, 1911), Engraulidae (Tab. I). The highest megalopae predation potential was detected in S. testudineus and Anchoa parva (Meek \& Hildebrand, 1923), Engraulidae, and the most important potential predator of juveniles was $S$. testudineus. All these fish species were abundant in the area, except for $S$. testudineus. In the case of this species, the predation potential was mostly due to high average number of preyed individuals.

\section{Trawl samplings}

The stomachs of Genidens genidens (Cuvier, 1829), Ariidae, contained the highest number of zoeae, whereas Bairdiella ronchus (Cuvier, 1830), Sciaenidae, showed the highest number of megalopae and juveniles per analyzed stomach (Tab. II and Fig. 4).

The stomach contents of G. genidens included $69 \%$ of brachyuran zoeae, $7 \%$ of megalopae, and 19\% juveniles. In some stomachs of this fish species, brachyuran immature forms accounted for $95 \%$ of the food items. In the stomach contents of $B$. ronchus, $46 \%$ of food items identified were brachyuran immature forms, $6 \%$ in the zoea phase, $15 \%$ in the megalopa phase and 25\% were young juveniles (Fig. 5).

The fish species that showed the highest zoeae predation potential were $G$. genidens and B. ronchus, in this sequence of importance. The same species showed the highest values of predation potential to megalopae and young juveniles, but their order of importance was the opposite.

When the amount of potentially preyed brachyuran immature forms was estimated for different tidal stages, no clear tendencies which could be related to events of dispersion and reinvasion of larvae were observed (Fig. 6).

\section{DISCUSSION}

The ichthyofauna of the Guaratuba Bay has been widely investigated, and previous studies have identified several fish species that could be potential predators of crab larvae, such as G. genidens (Chaves \& Vendel 1996, Souza \& Chaves 2000) Pomadasys corvinaeformis (Steindachner, 1868), Haemulidae (Chaves \& CorrêA 2000), and B. ronchus (Vendel \& Chaves 1998).

The results of the present study indicate that $P$. platana is likely to be the most important brachyuran larvae predator fish species in the studied environment, not only in terms of individual predation, but also in terms of predation potential. The high number of zoeae found in the analyzed stomachs $80.6 \%$ of the food items - versus low numbers of megalopae and the absence of juveniles in the stomach content analysis, indicates that this is the most important fish species preying on brachyuran zoeae. On the other hand, Aguiaro et al. (2003) found that this species eats different food items according to the local food availability. Based on this information, the high quantity of newly hatched zoeae present in the water during the samplings may explain the obtained data. 


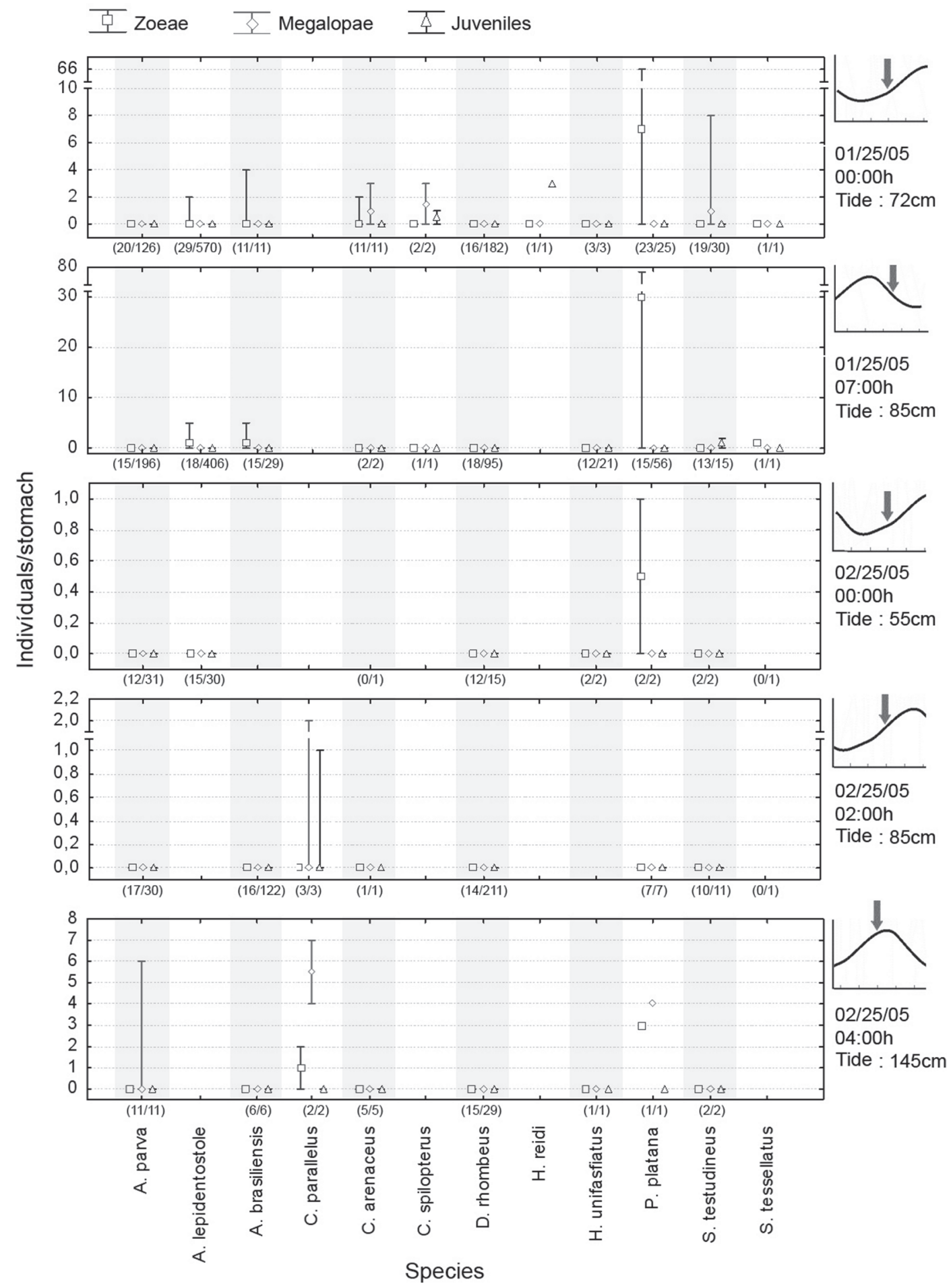

Figure 3. Median, maximum and minimum values of brachyuran immature forms identified in the stomach contents of fishes collected using manual nets in five different samplings. The number of analyzed stomachs and total amount of fishes collected are described between parentheses. At right side of graphics are described date, hour and tide dept in the moment of sampling. Note that y-axis of tide graphics have different scales. Species that did not preyed upon brachyurans were not included. 
Table II. Relation between fish species captured using trawl nets in Pinheiros river, Guaratuba Bay, and the average of brachyuran larvae and juveniles found in the stomach content analysis. Species that did not preyed upon brachyurans were not included in the table. The predation potential was determined by multiplying the average number of preyed larvae by the total number of captured fishes. Species typed in bold were captured both with manual nets and bottom trawling.

\begin{tabular}{|c|c|c|c|c|c|c|c|c|c|c|c|}
\hline \multirow[b]{2}{*}{ Fish species } & \multirow{2}{*}{$\begin{array}{c}\text { Fishes } \\
\text { captured }\end{array}$} & \multirow{2}{*}{$\begin{array}{l}\text { Analyzed } \\
\text { stomachs }\end{array}$} & \multirow{2}{*}{$\begin{array}{l}\text { Average total } \\
\text { length }(\mathrm{cm})\end{array}$} & \multicolumn{2}{|c|}{$\begin{array}{c}\text { Brachyuran } \\
\text { immature forms }\end{array}$} & \multicolumn{2}{|c|}{ Zoeae } & \multicolumn{2}{|c|}{ Megalopae } & \multicolumn{2}{|c|}{ Juveniles } \\
\hline & & & & Average & $\begin{array}{l}\text { Predation } \\
\text { potential }\end{array}$ & Average & $\begin{array}{l}\text { Predation } \\
\text { potential }\end{array}$ & Average & $\begin{array}{l}\text { Predation } \\
\text { potential }\end{array}$ & Average & $\begin{array}{l}\text { Predation } \\
\text { potential }\end{array}$ \\
\hline \multicolumn{12}{|l|}{ Achiridae } \\
\hline A. lineatus & 15 & 15 & 8.8 & 0.13 & 2.00 & 0.00 & 0.00 & 0.00 & 0.00 & 0.13 & 2.00 \\
\hline \multicolumn{12}{|l|}{ Sciaenidae } \\
\hline B. ronchus & 42 & 42 & 18.1 & 7.45 & 313.00 & 0.90 & 38.00 & 2.48 & 104.00 & 4.07 & 171.00 \\
\hline \multicolumn{12}{|l|}{ Centropomidae } \\
\hline C. parallelus & 20 & 20 & 17.0 & 0.90 & 18.00 & 0.00 & 0.00 & 0.00 & 0.00 & 0.90 & 18.00 \\
\hline \multicolumn{12}{|l|}{ Carangidae } \\
\hline C. chrysurus & 5 & 5 & 12.3 & 0.20 & 1.00 & 0.00 & 0.00 & 0.00 & 0.00 & 0.20 & 1.00 \\
\hline \multicolumn{12}{|l|}{ Paralichthyidae } \\
\hline C. arenaceus & 19 & 19 & 11.5 & 0.11 & 2.00 & 0.00 & 0.00 & 0.00 & 0.00 & 0.11 & 2.00 \\
\hline C. spilopterus & 21 & 21 & 12.1 & 0.48 & 10.00 & 0.00 & 0.00 & 0.29 & 6.00 & 0.19 & 4.00 \\
\hline \multicolumn{12}{|l|}{ Sciaenidae } \\
\hline C. acoupa & 1 & 1 & 11.9 & 2.00 & 2.00 & 0.00 & 0.00 & 0.00 & 0.00 & 2.00 & 2.00 \\
\hline \multicolumn{12}{|l|}{ Gerreidae } \\
\hline D. rhombeus & 123 & 84 & 12.8 & 0.05 & 5.86 & 0.02 & 2.93 & 0.02 & 2.93 & 0.00 & 0.00 \\
\hline \multicolumn{12}{|l|}{ Serranidae } \\
\hline D. radiale & 3 & 3 & 17.7 & 0.33 & 1.00 & 0.00 & 0.00 & 0.00 & 0.00 & 0.33 & 1.00 \\
\hline \multicolumn{12}{|l|}{ Paralichthyidae } \\
\hline E. crossotus & 42 & 42 & 8.3 & 0.43 & 18.00 & 0.00 & 0.00 & 0.00 & 0.00 & 0.43 & 18.00 \\
\hline \multicolumn{12}{|l|}{ Ariidae } \\
\hline G. genidens & 54 & 54 & 18.2 & 7.10 & 383.51 & 5.15 & 278.00 & 0.51 & 27.51 & 1.44 & 78.00 \\
\hline \multicolumn{12}{|l|}{ Tetraodontidae } \\
\hline L. laevigatus & 4 & 4 & 11.1 & 0.25 & 1.00 & 0.00 & 0.00 & 0.00 & 0.00 & 0.25 & 1.00 \\
\hline \multicolumn{12}{|l|}{ Sciaenidae } \\
\hline P. brasiliensis & 1 & 1 & 9.1 & 2.00 & 2.00 & 0.00 & 0.00 & 0.00 & 0.00 & 2.00 & 2.00 \\
\hline \multicolumn{12}{|l|}{ Triglidae } \\
\hline P. punctatus & 15 & 15 & 10.7 & 0.27 & 4.00 & 0.00 & 0.00 & 0.20 & 3.00 & 0.07 & 1.00 \\
\hline \multicolumn{12}{|l|}{ Serranidae } \\
\hline R. randalli & 7 & 7 & 12.7 & 1.29 & 9.00 & 0.00 & 0.00 & 0.29 & 2.00 & 1.00 & 7.00 \\
\hline \multicolumn{12}{|l|}{ Tetraodontidae } \\
\hline S. testudineus & 43 & 43 & 15.2 & 0.51 & 22.00 & 0.00 & 0.00 & 0.00 & 0.00 & 0.51 & 22.00 \\
\hline
\end{tabular}

Our results showed that, among the fish species captured during manual samplings, $S$. testudineus was the most important species preying on megalopae. $S$. testudineus was already identified by TARGETT (1978) as an important predator of brachyuran crabs in the Biscayne Bay, located in Florida, USA. C. parallelus regularly preyed upon megalopae, but due their low abundance in samples, the overall predation potential of this species was rather low. 


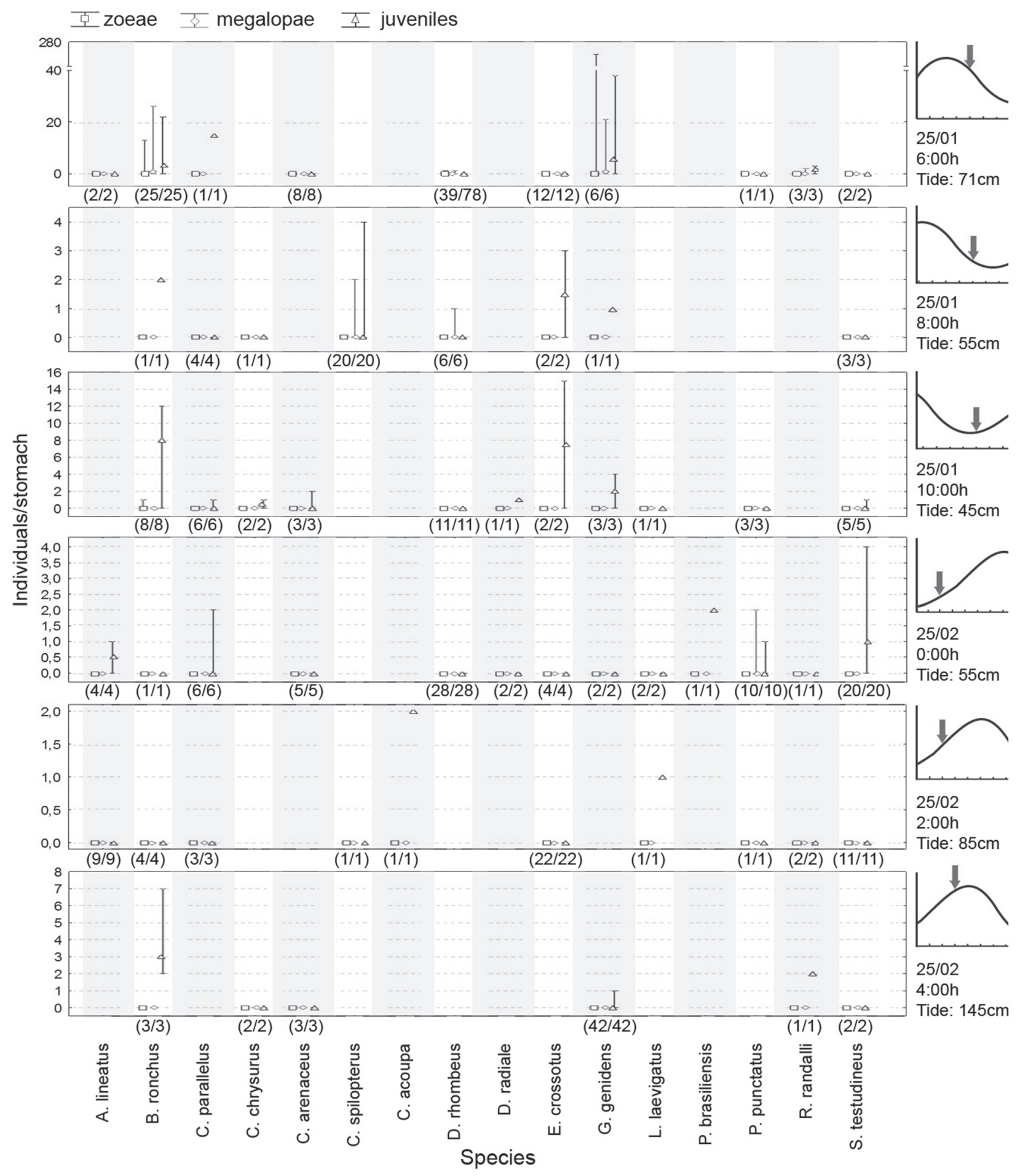

Figure 4. Median, maximum and minimum values of brachyuran immature forms identified in the stomach contents of fishes collected using bottom trawling in six different samplings. The number of analyzed stomachs and total amount of fishes collected are described between parentheses. At right side of graphics are described date, hour and tide dept in the moment of sampling. Note that $y$-axis of tide graphics have different scales. Species that did not preyed upon brachyurans were not included. 


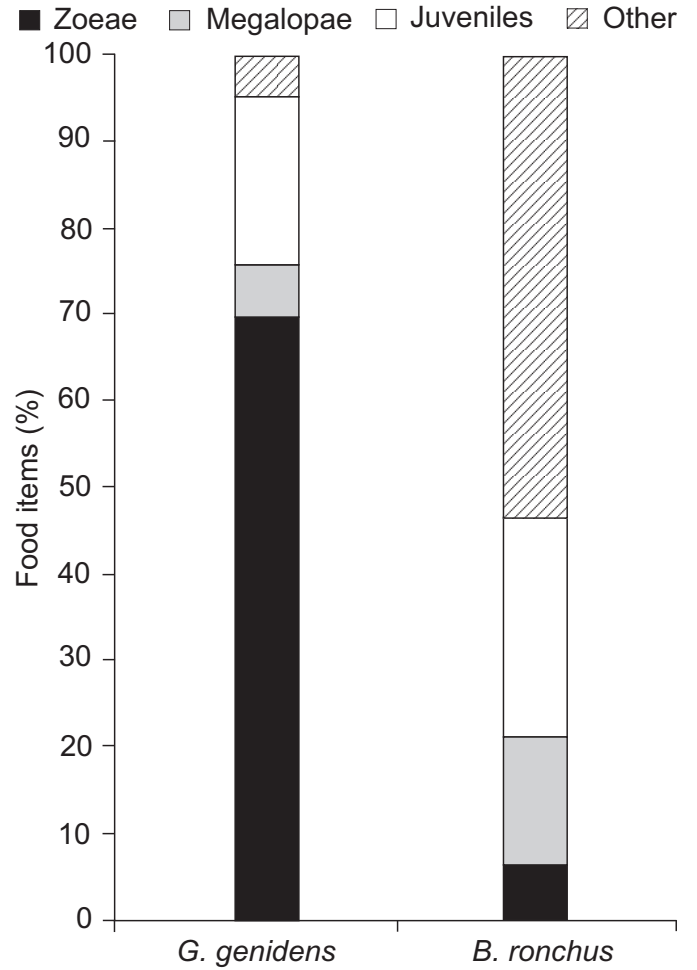

Figure 5. Food items (in percentage) found in the stomachs of fishes captured in Pinheiros river, Guaratuba Bay, using trawl nets and identified as important predator on brachyuran immature forms. The number of analyzed individuals is described in parentheses.

Among the species captured using trawl nets, the most important megalopa predator was $B$. ronchus. It was identified as the species with highest predation potential to brachyuran juveniles as well. Vendel \& Chaves (1998) described the feeding behavior B. ronchus in the Guaratuba Bay and showed that the most abundant food item in the stomach of individuals of this species are brachyuran crabs, especially during the summer, a result that is consistent with the present study.

Chaves \& Pichler (2000) studied the space-time variation of fish feeding behavior in the Guaratuba Bay and concluded that, during summer, G. genidens and B. ronchus show less stomach fullness in areas near the estuary opening, becoming increasingly fuller in areas inside the estuary. Based on this information, it is possible that the predation pressure observed in our work could be even higher if the study was carried out in more internal areas.

Two different fishing techniques were used in our work with the aim of capturing a wide set of fish species. Considering that these techniques were used in different biotopes, with different and complementary goals, the comparison of specific richness is not feasible. However, it is notable that fishes captured using different fishing techniques showed different total length, and this data provide important information about ecological relations.

Diapteurs rhombeus specimens were captured using both techniques. The ones captured using manual nets showed mean total length of $3.4 \mathrm{~cm}$ and was considerate the third most important specie on zoeae predation. Specimens of this same species, captured using trawl nets, showed a mean TL of $12.8 \mathrm{~cm}$ and no zoeae was found in stomach contents.

A similar pattern was observed when analyzing the stomachs of A. parva, C. parallelus, Citharichthys arenaceus Evermann, 1900, Paralichthyidae, Citharichthys spilopterus Günther, 1862, Paralichthyidae, and $S$. testudineus, in relation of megalopae predation. When captured using manual nets, their mean TL were $5.2,3.9,4.8,7.0$ and $3.8 \mathrm{~cm}$ respectively and showed high predation potential of this larval phase. However, when captured using traw nets, the mean TL was 17.2, 17.0, 11.5, 12.1 and 15.2 respectively and no megalopae was identified in stomachs.

Based on these results, we can conclude that some species identified as important predators of brachyuran larvae and juveniles, e. g. S. testudineus and $D$. rhombeus, may behave like that only during limited periods of life. Some others, e. g. Atherinella brasiliensis (Quoy and Gaimard, 1825) (Atherinopsidae) and $P$. platana, may exert predation on brachyuran larvae during all life stages.

Finally, the data recommend that brachyuran crabs restocking efforts performed in Guaratuba Bay should consider the development of strategies to avoid or, at least, reduce the access of fishes to released early juvenile stages, especially to megalopae. Considering that, in general, predation potential was 8.5 times lower to juveniles than to megalopae, releasing immature forms produced in laboratory in the juvenile phase or releasing megalopae into tethered areas and maintaining them under this condition until they reach the juvenile phase may be tested as a method to reduce losses given to fish predation.

\section{LITERATURE CITED}

Aguiaro, T.; C.W.C. Branco; J.R. Verani \& E.P. Caramaschi. 2003. Diet of the Clupeid Fish Platanichthys platana (Regan, 1917) in Two Different Brazilian Coastal Lagoons. Brazilian Archives of Biology and Technology 46 (2): 215-222.

Anger, K.; E. SpivaK; C. Bas; D. Ismael \& T. Luppi. 1994. Hatching rhythms and dispersion of decapod crustacean larvae in a brackish coastal lagoon in Argentina. Helgoland Marine Research 48 (4): 445-466.

Ariyama, H. 2000. Studies on Ecology and Stock Enhancement of Swimming Crab Portunus trituberculatus in Osaka Bay. Bulletin of the Osaka Prefectural Fisheries Experimental Station 12: 1-90.

Bigarella, J.J.; R. Doubek \& R. Salamuni. 1957. Planta geológica provisória da Baía de Guaratuba. Conselho Nacional de Pesquisa. Curitiba, Paraná, 8,6p.

Chaves, P. \& J.L. Bouchereau. 2004. Trophic organization and functioning of fish populations in the Bay of Guaratuba, 


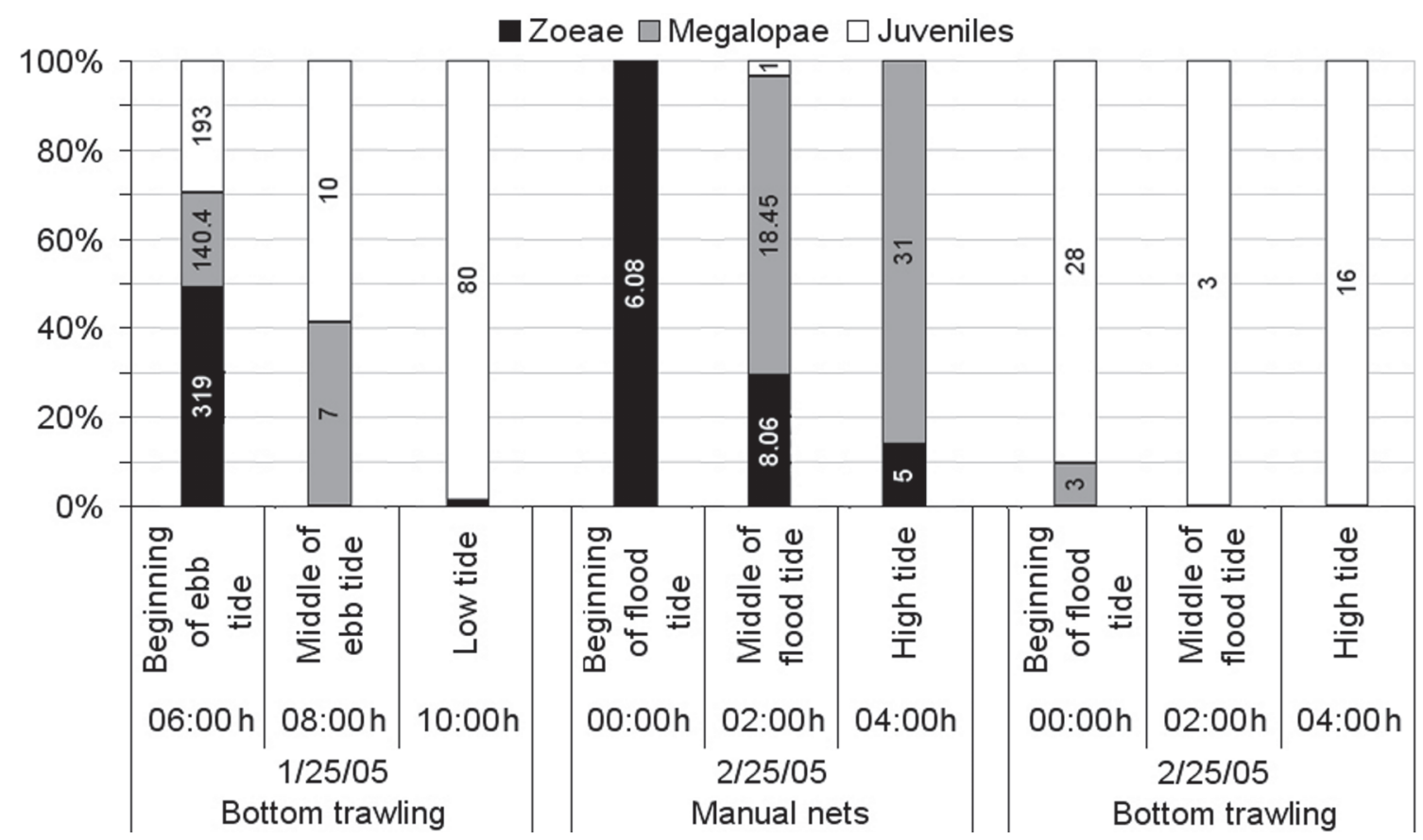

Figure 6. Estimate of relative and absolute amount of potentially preyed brachyurans immature forms in the different sampling efforts. Numbers into bars indicates absolute values.

Brazil, on the basis of a trophic contribution factor. Acta Adriatica 45 (1): 83-94.

ChAves, P.T.C. \& M.F.M. CoRRÊA. 1998. Composição ictiofaunística da área de manguezal da Baía de Guaratuba, Paraná, Brasil. Revista Brasileira de Zoologia 15 (1): 195-202.

Chaves, P.T.C. \& M.F.M. CorrêA. 2000. Temporary use of a coastal ecosystem by the fish Pomadasys corvinaeformis (Perciformis: Haemulidae) at Guaratuba Bay, Brasil. Revista Brasileira de Oceanografia 48 (1): 1-7.

Chaves, P.T.C. \& H.A. Pichler. 2000. Variações espaço-temporais na atividade alimentar de peixes num ambiente estuarino (Baía de Guaratuba, Paraná, Brasil). Acta Biologica Leopoldensia 22 (2): 277-287.

Chaves, P.T.C. \& A.L. Vendel. 1996. Aspectos da alimentação de Genidens genidens (Valenciennes) (Siluriformes, Ariidae) na Baía de Guaratuba, Paraná. Revista Brasileira de Zoologia 13 (3): 669-675.

Chaves, P.T.C. \& A.L. Vendel. 1997. Indicadores reprodutivos das espécies de Citharichthys Bleeker (Teleostei, Pleuronectiformes) na Baía de Guaratuba, Paraná, Brasil. Revista Brasileira de Zoologia 14 (1): 73-79.

Christy, J.H. 1978. Adaptive significance of reproductive cycles in the fiddler crab Uca pugilator: a hypothesis. Science 199: 453-456.

Christy, J.H. 2003. Sincronía reproductiva y de dispersión larval en cangrejos intermareales: la hipótesis anti-depredador. Revista Chilena de Historia Natural 76: 177-185.
Decoursey, P.J. 1983. Biological timing, p. 107-162. In: F.J. Vernberg \& W.B. Vernierg (Eds). The biology of Crustacea: Behavior and ecology. New York, Academic Press, 388p.

ForWARD JR, R.B. 1988. Larval release rhythms of decapod crustaceans: an overview. Bulletin of Marine Science 41: 165-176.

Hunt, H.L. \& R.E. Scheibling. 1997. Role of early post-settlement mortality in recruitment of benthic marine invertebrates. Marine Ecology Progress Series 155: 269-301.

Keough, M.J. \& B.J. Downes. 1982. Recruitment of marine invertebrates: the role of active larval choices and early mortality. Oecologia 54 (3): 348-352.

Lindquist, N. \& M.E. Hay. 1996. Palatability and chemical defense of marine invertebrate larvae Ecological Monographs 66 (4): 431-450.

MorgAN, S.G. 1990. Impact of planktivorous fishes on dispersal, hatching and morphology of estuarine crab larvae. Ecology 71: 1639-1652.

Morgan, S.G. 1995. The timing of larval release, p. 157-191. In: L. McEDWARD (Ed.). Ecology of marine invertebrate larvae. Boca Raton, Florida CRC Press,464p.

Morgan, S.G. \& J.H. Christy. 1994. Species-Specific hierarchies of rhythms regulating reproductive timing: plasticity, constraint and optimality in larval release. Ecology 70: 462-482.

Olafsson, E.B.; C.H. Peterson \& W.G. Ambrose Jr. 1994. Does recruitment limitation structure populations and communities of macro-invertebrates in marine soft sediments: The 
relative significance of pre- and post-settlement process. Oceanography and Marine Biology: an annual review 32: 65-109.

Roughgarden, J. \& H. Possingham. 1988. Recruitment dynamics in complex life cycles. Science 241: 1460-1466.

Secor, D.H.; A.H. Hines \& A. R.Place. 2002. Japanese Hatcherybased Stock Enhancement: Lessons for the Chesapeake Bay Blue Crab. Maryland, Sea Grant Publication, 46p.

Souza, M.A.M. \& P.T.C. Chaves. 2000. Influência do tamanho individual sobre a dieta de Genidens genidens (Teleostei, Ariidae) na Baía de Guaratuba (PR, Brasil). Acta Biologica Leopoldensia 22 (2): 249-260.

TARGETT, T.E. 1978. Food resource partitioning by the pufferfishes Sphoroides splengleri and S. testudineus from Biscayne Bay,
Florida. Marine Biology 49: 83-91.

Thorso, N.G. 1950. Reproductive and larval ecology of marine bottom invertebrates. Biological Reviews 25: 1-45.

Vendel, A.L. \& P.T.C. Chaves. 1998. Alimentação de Bairdiella ronchus (Cuvier) (Perciformes, Scianidae) na Baía de Guaratuba, Paraná, Brasil. Revista Brasileira de Zoologia 15 (2): 297-305.

Young, C.M. \& F.S. ChIAN. 1987. Abundance and distribution of pelagic larvae as influenced by predation, behavior and hydrographic factors, p. 385-463 In: A.C. Giese; J.S. PeArSe \& V.B. PEARSE. Reproduction of marine invertebrates. Blackwell, Academic Press, 546p.

Ziegler, T.A. \& R.B. Forward JR. 2005. Larval Release Rhythm of the Mole Crab Emerita talpoida. Biological Bulletin 209: 194-203.

Submitted: 12.IX.2008; Accepted: 12.VI.2009.

Editorial responsability: Maria Lúcia Negreiros-Fransozo 